\title{
RAPID DETECTION OF A POINT MUTATION IN THYROID-STIMULATING HORMONE $\beta$-SUBUNIT GENE CAUSING CONGENITAL ISOLATED THYROID-STIMULATING HORMONE DEFICIENCY
}

\author{
Ryogo Mori, ${ }^{1}$ Tomoko Sawai, ${ }^{1}$ Ei-ichi Kinoshita, ${ }^{1}$ \\ Tsuneyoshi BabA, ${ }^{1}$ Tadashi Matsumoto, ${ }^{1}$ Masaaki Yoshimoto, ${ }^{1}$ \\ Yoshiro TsujI, ${ }^{1}$ Yukishige Satake, ${ }^{2}$ and Kei SAwada ${ }^{2}$ \\ ${ }^{1}$ Department of Pediatrics, Nagasaki University School of Medicine, \\ Sakamoto-machi 7-1, Nagasaki 852, Japan \\ ${ }^{2}$ Department of Pediatrics, Kochi Prefectural Seinan Hospital, Uyama 1973, \\ Nakamura, Kochi 797, Japan
}

\begin{abstract}
Summary Previous study showed that congenital isolated TSH deficiency in Japan is resulted exclusively from a G-A transition at nucleotide 145 in exone 2 of the TSH $\beta$-subunit gene. All reported cases were from the inbred in Shikoku Island. We describe here a 10 -year-old boy with hereditary TSH deficiency in the same area. The patient was born with a weight of $3,225 \mathrm{~g}$ to non-consanguineous parents. Evaluation at age 2 months revealed typical manifestations of cretinism without goiter. Serum $\mathrm{T} 4, \mathrm{~T} 3$, and TSH values were $2.53 \mu \mathrm{g} / \mathrm{dl}, 107 \mathrm{ng} / \mathrm{dl}$, and $0.5 \mu \mathrm{U} / \mathrm{ml}$, respectively. A TRH stimulation test showed no increment of serum TSH value. Other anterior pituitary hormone levels were all within the normal range. Two oligonucleotide primers Tla and Tlb were synthesized according to the sequence data. Amplified 169 bp nucleotides in exon 2 of the TSH $\beta$ gene with this primer set were digested with MaeI. Both the phenotypically normal brother and normal controls showed only the 169 bp fragment, whereas the proband showed 140 and 29 bp fragments and both parents showed three fragments; 169,140 , and $29 \mathrm{bp}$. These results were consistent with the point mutation of $\operatorname{TSH} \beta$ gene in Japanese patients with congenital isolated TSH deficiency. Our PCR method with MaeI digestion contributes to the rapid detection of the homozygous patient and the heterozygous carrier.
\end{abstract}

Key Words congenital isolated thyroid-stimulating hormone deficiency, hypothyroidism, thyroid-stimulating hormone $\beta$ chain, polymerase chain reaction (PCR) 


\section{INTRODUCTION}

Congenital isolated thyroid-stimulating hormone (TSH) deficiency (CITD) originally described Miyai et al. (1971) is a rare autosomal recessive disorder. It is known that Japanese families with CITD are all from the inbred within the western district in Shikoku Island (Hayashizaki et al., 1990). TSH is a heterodimer molecule consisting of a specific $\beta$-subunit and an $\alpha$-subunit common to other glycoprotein hormones. The human TSH $\beta$-subunit $\left(\mathrm{TSH}_{\beta}\right)$ gene was recently cloned by Hayashizaki et al. (1985). It was disclosed that the identical single nucleotide substitution in the TSH $\beta$ gene is the cause of all CITD in Japan (Hayashizaki et al., 1990). In the present report, we describe another Japanese male patient with CITD from the same area, together with a successful rapid method for identification of the supposed mutation in the TSH $\beta$ gene with polymerase chain reaction (PCR) followed by restriction endonuclease digestion.

\section{CASE REPORT}

The patient was born uneventfully with a weight of $3,225 \mathrm{~g}$. His parents were from the western district of Shikoku Island, but were said to be non-consanguineous. Since neonatal period, decreased activity, poor sucking, failure to thrive and prolonged hyperbilirubinemia had appeared. The first evaluation at age 2 months revealed typical manifestations of cretinism, such as dried and pale skin, a macroglossia, an umbilical hernia, hypothermia, and muscular hypotonia. He had no goiter. Basal values of serum T4, T3, TSH, and free T4 index were $2.53 \mu / \mathrm{dl}, 107$ $\mathrm{ng} / \mathrm{dl}, 0.5 \mu \mathrm{U} / \mathrm{ml}$, and 0.84 , respectively. A TRH stimulation test showed no increment of serum TSH value and normal increment of serum prolactin value. Both conventional insulin and LHRH stimulation tests revealed normal increment of serum growth hormone, LH, FSH, and plasma ACTH values. The ${ }^{131}$ I thyroid scintigram showed no thyroidal uptake of iodide. The diagnosis of CITD was made and the administration of 1-thyroxine was initiated at age 2 months. $\mathrm{He}$ is now 10 year old and normal in physical and mental development.

\section{METHODS AND RESULTS}

We assumed that the present case would have the gene mutation identical to that in other Japanese patients, and attempted to detect the mutation by PCR followed by Mael digestion. Genomic DNA was extracted from peripheral blood leukocytes of the proband, parents, a phenotypically normal brother and of control individuals. Oligonucleotide primers Tla (5'-ACTGCTCTCTTTCTGATGTC-3') and T1b (5'-TTGATGTATGGGCACAGTA-3') were synthesizeda cording to the 


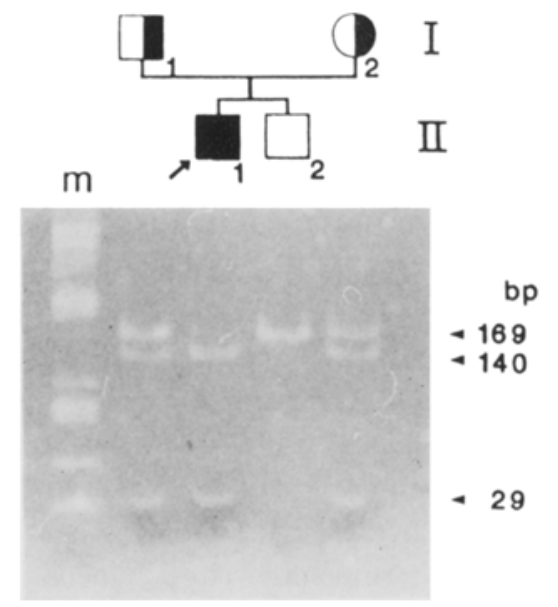

Fig. 1. PCR products of family members. Amplified DNAs from both parents, the proband and the brother were digested with a restriction endonuclease MaeI. Size marker (m) is $A l u \mathrm{I}$ digests of pUC18 plasmid.

sequence data by Hayashizaki et al. (1985). By the PCR with this primer set, a $169 \mathrm{bp}$ fragment in exon 2 of the $\mathrm{TSH}_{\beta}$ gene was amplified. The mutation described by Hayashizaki et al. (1990) exists in this exon. If the same point mutation exists at the expected codon in exon 2, the amplified DNAs could be digested to 140 and 29 bp fragments by the restriction endonuclease MaeI. PCR amplification of genomic DNA $(0.5 \mu \mathrm{g})$, electrophoresis and extraction of amplified DNA was performed as described elsewhere (Kinoshita et al., 1991). Amplified DNA (10 $\mu$ ) was digested with a restriction endonuclease $\mathrm{MaeI}$ at the condition of manufacturer's recommendation. Digested DNA was electrophoresed in $6 \%$ polyacrylamide gel, then stained with ethidium bromide and photographed.

After amplification of genomic DNA, a 169 bp fragment was detected in all the samples. When the DNA was digested with MaeI, both the brother and normal controls showed only a 169 bp fragment, whereas the proband showed 140 and $29 \mathrm{bp}$ fragments. Both of the parents showed three fragments: 169, 140, and 29 bp (Fig. 1).

\section{DISCUSSION}

Of six families with CITD described in the literature, three are from Japan (Hayashizaki et al., 1990), one from France (Labbe et al., 1984), and two from Greece (Dacou-Voutetakis et al., 1990). To date, two different gene mutations causing CITD were reported. In the Japanese families, a G-A transition at nucleotide 145 in the TSH $\beta$ gene, coding the so-called "CAGYC" region which are conserved among almost all $\beta$-subunits of mammalian glycoprotein hormones, alters the 
molecular conformation of the $\beta$-subunit to interfere the association with the $\alpha$. subunit (Hayashizaki et al., 1989). On the other hand, in the Greek families, a G-T transversion at nucleotide 94 in exon 2 caused a nonsense mutation (DacouVoutetakis et al., 1990). Digested DNA fragments patterns after PCR amplification in the present study confirmed the identical mutation in this family with that in other Japanese families, i.e., the proband was homozygous and each parent was heterozygous for this mutation, while the brother had two normal alleles.

The results in the patient, together with previous reports, strongly supported that the gene mutation in this district has been originated from a single founder. Adding the patient to the previous reports, the gene frequency and frequency of heterozygous carriers increase more than those estimated by Miyai et al. (1988). In most parts of Japan including Shikoku Island, neonatal mass-screening for congenital hypothyroidism is performed by only TSH measurement to find the patients due to primary hypothyroidism. Thus, it needs to screen with both TSH and T4 measurements in Shikoku Island, particularly in the western district. Our PCR method with Mael digestion is very convenient and useful to diagnose patients homozygous for the mutant gene and heterozygous carriers. It may also apply to the prenatal diagnosis of the disorder.

Acknowledgments We thank Dr. I. Hibi, National Children Hospital (Tokyo), for informing about data of thyroid function of the patient in infancy.

\section{REFERENCES}

Dacou-Voutetakis, C., Feltquate, D.M., Drakopoulou, M., Kourides, L.A. and Dracopoli, N.C. 1990. Familial hypothyroidism caused by a nonsense mutation in the thyroid-stimulating hormone $\beta$ subunit gene. Am. J. Hum. Genet. 46: 988-993.

Hayashizaki, Y., Miyai, K., Kato, K. and Matsubara, K. 1985, Molecular cloning of the human thyrotropin $\beta$-subunit gene. FEBS Lett. 188: 394-400.

Hayashizaki, Y., Hiraoka, Y., Endo, Y., Miyai, K. and Matsubara, K. 1989. Thyroid-stimulating hormone (TSH) deficiency caused by a single base substitution in the CAGYC region of the B-subunit. EMBO J. 8: 2291-2296.

Hayashizaki, Y., Hiraoka, Y., Tatsumi, K., Hashimoto, T., Furuyama, J., Miyai, K., Nishijo, K., Matsuura, M., Kohno, H., Labbe, A. and Matsubara, K. 1990. Deoxyribonucleic acid analyses of five families with familial inherited thyroid stimulating hormone deficiency. J. Clin. Endocrinol. Metab. 71: 792-796.

Kinoshita, E., Matsumoto, T., Kondoh, T., Yoshimoto, M., Niikawa, N. and Tsuji, Y. 1991. Deletion pattern in the 21 -hydroxylase gene detected by polymerase chain reaction. Acta Paediatr. Jpn. 33: 1-5.

Labbe, A., Dubray, C., Gaillard, G., Besse, G., Assali, P. and Malpuech, G. 1984. Familial growth retardation with isolated thyroid-stimulating hormone deficiency. Clin. Pediatr. 23: 675678.

Miyai, K., Azukizawa, M. and Kumahara, Y. 1971. Familial isolated thyrotropin deficiency with cretinism. N. Engl. J. Med. 285: 1043-1048.

Miyai, K., Hayashizaki, Y., Hiraoka, Y., Tatsumi, K., Matsubara, K., Endo, Y., Nishijo, K., Matsuura, M., Kohno, H. and Labbe, A. 1988. Familial hypothyroidism due to thyrotropin gene abnormality. In Progress in Endocrinology (Proceedings of the 8th International Congress of Endocrinology), Imura, H., Shizume, K., Yoshida, S., eds., Excepta Medica, AmsterdamNew York-Oxford, Vol. 1, pp. 545-550. 